\title{
Possibility of net phytoplankton primary production in the turbid Schelde Estuary (SW Netherlands)
}

\author{
Jacco Kromkamp, Jan Peene
}

Netherlands Institute of Ecology, Centre for Estuarine and Coastal Ecology, Vierstraat 28, 4401 EA Yerseke, The Netherlands

\begin{abstract}
Phytoplankton primary production was studied in the turbid estuary of the river Schelde (The Netherlands). Measured rates of gross primary production were comparable to other estuaries. Respiration rates were calculated as being a fixed percentage of the maximum rate of photosynthesis $\left(P_{\max }^{B}\right)$. We calculated that net primary production would be possible only when the rate of respiration was less than $1.5 \%$ of $P^{B}$ max. This respiration rate seemed too low to be realistic, but was necessary to explain the observed growth of phytoplankton. Near the maximum turbidity zone, no net annual primary production could be calculated. Maximum rates of photosynthesis were similar to those reported in the literature. Phytoplankton had relatively high rates of photosynthetic affinity $\left[\alpha^{B}, 0.032\right.$ to 0.043 $\left.\mathrm{mg} \mathrm{C} \mathrm{mg}{ }^{-1} \mathrm{chl} \mathrm{h}^{-1}\left(\mu \mathrm{mol} \mathrm{m} \mathrm{m}^{-2} \mathrm{~s}^{-1}\right)^{-1}\right]$, although they were within the range reported in the literature. When lower values for $\alpha^{B}$ were used, estimates of net primary production decreased significantly. We propose that it is probably better to use the $0.1 \%$ light level as the base of the photic depth than the $1 \%$ light level when considering the critical depth. We also calculated respiratory losses with a simple 2compartment model assuming that respiration was determined by maintenance processes and by the growth rate. Using this model with published parameter values, the calculated respiratory losses in the summer were comparable to the results in which a respiration rate equal to $1.5 \%$ of $P_{\max }^{B}$ was assumed. Hence, this physiologically more sound approach allowed calculation of net primary production whereas the more rigid approach assuming that respiration is a fraction of $P_{\text {max }}^{B}$ did not.
\end{abstract}

KEY WORDS: Phytoplankton Estuary - Net primary production - Light climate - Respiration - Euphotic depth

\section{INTRODUCTION}

Primary production by phytoplankton in estuaries can be high in comparison to nearby coastal areas due to relatively high nutrient concentrations. This potential production is not always reached because estuaries, especially the well-mixed coastal plain estuaries, are often very turbid, imposing light limitation on primary production by algae. With some exceptions the Ems Estuary (Colijn 1983), the Dutch Wadden Sea (Cadee 1993), the Bristol Channel (Joint \& Pomroy 1981) and the Westerschelde (Van Spaendonk et al. 1993) - annual primary production by phytoplankton is not well studied in European estuaries.

The Schelde Estuary (Fig. 1) is a turbid, eutrophic coastal plain estuary in the southwest of The Nether- lands. It is a system of relatively deep tidal channels separated by intertidal flats. The estuary is fed by the river Schelde, which has a catchment area of approximately $19500 \mathrm{~km}^{2}$ (Heip 1989). A salinity gradient exists which increases from approximately $2.5 \mathrm{psu}$ near Antwerpen to 29 psu at the seaward boundary near Vlissingen (see Fig. 1). The residence time of water in the entire estuary is approximately $75 \mathrm{~d}$ (Heip 1989). As the estuary is heavily polluted by domestic and industrial waste, bacterial growth is intensive (Billen et al. 1988, Goosen et al. 1992), leading to oxygen depletion in the more central and eastern parts of the estuary. Oxygen saturation levels below $10 \%$ are found in the river Schelde. Nutrient concentrations are high (Kromkamp et al. in press). The range in the seasonal growth period (April 1 to September 30) between 


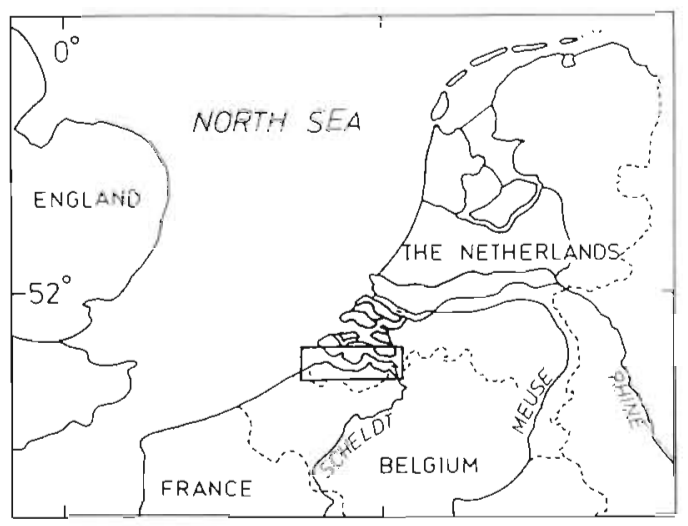

Fig. 1. Sampling stations in the Schelde Estuary, The Netherlands Average salinity (psu) is given in parentheses

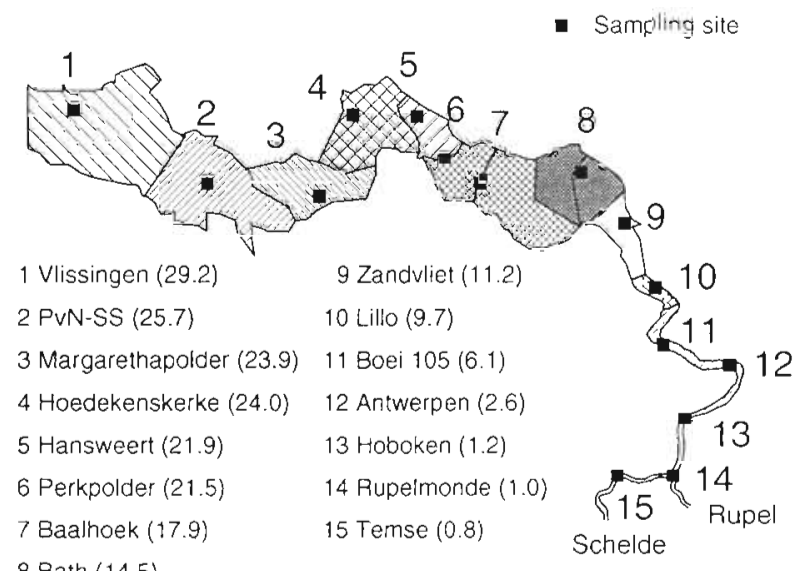

8 Bath (14.5)

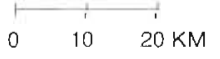

seawater (seaward boundary) and freshwater is 70 to $600 \mu \mathrm{M}$ for dissolved inorganic nitrogen, 3 to $20 \mu \mathrm{M}$ for phosphate and 5 to $230 \mu \mathrm{M}$ for silicate. Average annual total suspended matter content changes from more than $80 \mathrm{mg} \mathrm{l}^{-1}$ at the freshwater boundary to less than $30 \mathrm{mg} \mathrm{l}^{-1}$ at the seaward boundary. As nutrient concentrations are very high, they do not limit phytoplankton growth (Van Spaendonk et al. 1993, Soetaert et al. 1994).

As the water column is generally well mixed, phytoplankton experience a varying light regime. However, in the central and western parts of the basin, we regularly observed a temporary salinity difference of up to 2 to 3 psu between the surface and the bottom, which lasted a few hours. It was observed by Van Spaendonk et al. (1993) that in the Westerschelde the euphotic depths might be considerably smaller than the mixing depths (in this study taken as the average bottom depth of each compartment), indicating that during daylight phytoplankton experience light intensities too low to support photosynthesis. If the time spent below the photic depth is too long, the critical depth will be exceeded and the respiration rate on a daily scale will be higher than the photosynthesis rate; net growth is no longer possible, leading to loss of cell mass and eventually to the decline of populations. It is generally assumed that the critical depth necessary to sustain phytoplankton populations is 5 to 6 times the euphotic depth (taken as the depth to which $1 \%$ of the light penetrates; e.g. Grobbelaar 1985, Cloern 1987, Alpine \& Cloern 1988).

Generally, phytoplankton respiration is not taken into account when studying primary production. Cole et al. (1992) questioned whether a positive carbon balance was possible in the turbid Hudson River Estuary, USA. Results of Fichez et al. (1992) and Van Spaen- donk et al. (1993) showed that net phytoplankton growth did occur in the turbid estuaries, despite the fact that the ratio of euphotic depth to mixing depth was unfavourable.

We studied primary production in the Westerschelde and a portion of the Schelde River as part of an ecosystem study and were interested in the carbon balance of the phytoplankton. In this paper net phytoplankton production is estimated under the assumption that respiration $(R)$ is a fixed percentage of the maximum rate

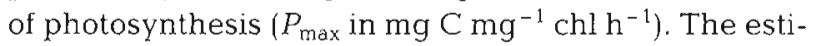
mated respiratory losses are compared to a physiological model where respiration is split into maintenance respiration and respiration which varies linearly as a function of primary production.

\section{METHODS}

Water sampling and physical measurements. In 1991 all stations (Fig. 1) were sampled every 2 wk from March to October and once a month for the rest of the year. Temperature, $\mathrm{pH}$, oxygen concentration and salinity were measured in situ using a CTD-probe (H20-datasonde coupled to a Surveyor 3, Hydrolab). Only data from surface samples are presented here. Light attenuation was measured using Licor LI-192SB cosine-corrected light sensors which were connected to a Licor LI-185B quantum meter.

Chemical analyses. Seston dry weight was determined gravimetrically after drying at $70^{\circ} \mathrm{C}$.

Samples for pigment analyses of phytoplankton were filtered onto glass fibre filter (Schleicher \& Schuell, no. 6). Filters and sediment samples were extracted in $90 \%$ acetone and pigments were determined using reversed phase high-performance liquid 
chromatography (HPLC) according to Gieskes et al. (1988).

Primary production of phytoplankton. Duplicate $50 \mathrm{ml}$ samples [to which $200 \mu \mathrm{l}$ of $185 \mathrm{kBq} \mathrm{ml}^{-1}{ }^{14} \mathrm{C}$ $\mathrm{NaHCO}_{3}$ (Amersham) was added] were incubated in a rotating incubator (Vegter \& de Visscher 1984) on board the RV 'Luctor' immediately after sampling at in situ temperatures. The samples in the incubator were exposed to 10 different irradiances (excluding the dark bottles) up to a maximal irradiance of $810 \mu \mathrm{mol} \mathrm{m} \mathrm{m}^{-2} \mathrm{~s}^{-1}$. After incubation the samples were gently filtered over $0.45 \mu \mathrm{m}$ nitrocellulose filters (Schleicher \& Schuell BA23). The incubation period was $2 \mathrm{~h}$. Filters were placed in $\mathrm{HCl}$ fumes for $30 \mathrm{~min}$, air dried and counted in a Beckmann LSC (LS5000TD). A scintillation cocktail was prepared using $0.5 \%(\mathrm{w} / \mathrm{v})$ PPO (2,5-diphenyloxazol, p.a. Merck) in toluene (Baker, technical grade). Correction for quench took place using the shift in the Compton peak (H-number) according to the manufacturer's instructions. Dissolved inorganic carbon was determined by potentiometric titration. Primary production was calculated using an isotope discrimination factor of 1.05 . The rate of carbon fixation in the dark bottles was subtracted from that in the light bottles in order to avoid overestimates of primary production by phytoplankton due to chemosynthetic processes.

The photosynthesis/irradiance $(P / I)$ curves were fitted according to Eilers \& Peeters (1988):

$$
P^{B}=E /\left(a E^{2}+b E+c\right)
$$

where $P^{B}$ is the rate of photosynthesis, $E$ is the (scalar)

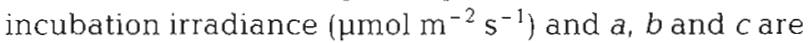
fit-constants. $P_{\max }^{B}[1 /(b+2 \sqrt{a C})]$, the photosynthetic capacity, is the maximal rate of photosynthesis ( $\mathrm{mg} \mathrm{C}$ $\left.\mathrm{mg}^{-1} \mathrm{chl} \mathrm{h}^{-1}\right)$ and $\alpha^{B}(1 / \mathrm{c})$ is the photosynthetic effi-

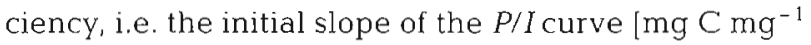

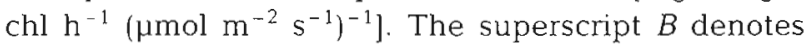
that $P / I$ characteristics were calculated per mg chlorophyll a (chl a). The irradiance in the incubator was measured with a $4 \pi$ sensor (Biospherical Instruments). Because the incubation time of $2 \mathrm{~h}$ was relatively short, it was assumed that the measured rates of photosynthesis equalled gross rates (Williams 1993).

Water column production was calculated from the fitted $P / I$ curve, the attenuation coefficient and hourly incident irradiance. The latter was measured close to Stn 5 (Hansweert) with a Kipp solarimeter fitted with a PAR (400 to $700 \mathrm{~nm}$ ) sensor. Because the instrument broke down in 1991, hourly light data were obtained from a local station of the Dutch Meteorological Institute (KNMI). However, the sensor they used integrated radiation from 300 to $2200 \mathrm{~nm}$. A conversion factor $(0.33 \pm 0.02)$ was calculated after comparing 500 hourly data points. Integral column production corrected for basin morphology (because there are large tidal flats and shallow areas in the Westerschelde which take up approximately $25 \%$ of the total surface area) was calculated according to Klepper (1989), by calculating primary production per $\mathrm{m}^{2}$ in small layers of $25 \mathrm{~cm}$ depth which were then multiplied by the surface area at the particular depth of the compartment. After addition of the values from all layers, the water column production ( $\mathrm{mg} \mathrm{C} \mathrm{m}^{-2} \mathrm{~h}^{-1}$ ) was calculated by dividing the total production in the compartment by the surface area of that compartment. Production rates between sampling points were calculated using measured irradiance data and assuming that the $P / I$ characteristics and photic depths did not change during the calculation interval (the week before and the week following the sampling date). Carbon turnover rates ( $P / B$ ratios) were calculated by dividing the column production $(P)$ by the carbon content of the phytoplankton in the water column (biomass, B). The carbon content of the phytoplankton was calculated from the chlorophyll a content, assuming a $\mathrm{C} / \mathrm{chl}$ a ratio of 30 . This ratio was chosen because it was the mean ratio found in phytoplankton samples taken from the nearby Oosterschelde Estuary during the period 1982 to 1990 , from which volume measurements were determined microscopically (Wetsteyn \& Kromkamp 1994). This way high $\mathrm{C} / \mathrm{chl}$ a ratios were prevented which would have otherwise occurred if the carbon content was calculated from particulate (detrital) organic carbon measurements. Although the $\mathrm{C} / \mathrm{chl}$ a ratio can vary depending on environmental conditions, recalculation of net primary production with assumed $\mathrm{C} / \mathrm{chl}$ a ratios of 20 or 50 again led to the conclusion that the respiration rate was higher than the gross primary production rate, assuming that the respiration rate was $>5 \%$ of $P_{\max }^{B}$.

\section{RESULTS}

\section{Euphotic depths}

The ratio of the average annual mixing depth $\left(Z_{\mathrm{m}}\right.$ taken as the total water depth) relative to the euphotic depth $\left(Z_{\text {eu }}\right.$, taken as the depth to which $1 \%$ of the surface light penetrates) is plotted in Fig. 2. When it is assumed that the euphotic depth is equal to the depth to which $1 \%$ of the surface irradiance penetrates, the $Z_{\mathrm{m}} / Z_{\text {eu }}$ ratio varies between 4 and 6 in the outer part of the estuary, and increases to more than 10 in the limnic part. Large variations (up to $100 \%$ at some occasions) occurred at each station, mainly due to tidal variations (i.e. resuspension of sediments). The dashed horizontal line at a $Z_{\mathrm{m}} / Z_{\text {eu }}$ ratio of 5 in Fig. 2 indicates the critical 


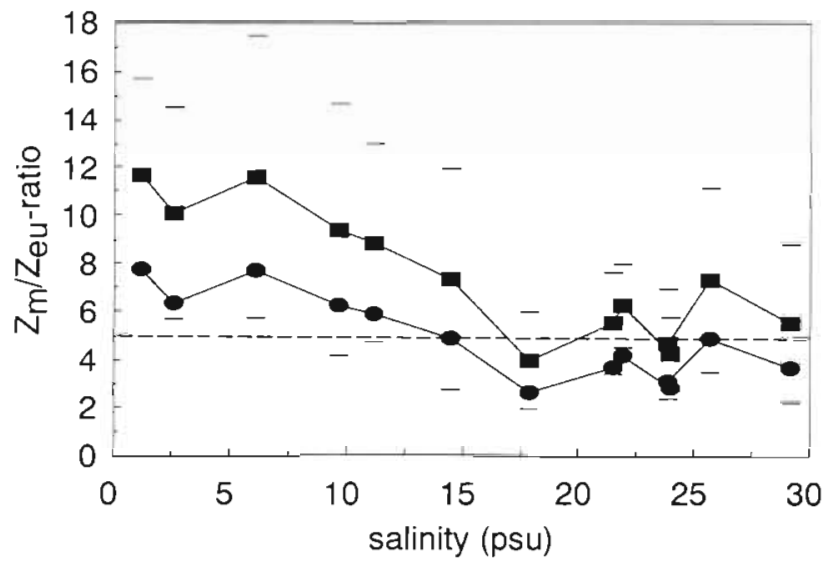

Fig. 2. Annual average mixing depth to euphotic depth ratio $\left(Z_{\mathrm{Tn}} / Z_{\mathrm{eu}}\right)$ for each station. The euphotic zone was taken as the depth to which $1 \%$ of the surface irradiance penetrates ( $\square$ ). The short dashes show the standard error of the mean. (O) Indicates when the depth of the euphotic depth would equal $0.1 \%$ of the surface irradiance. The dashed line indicates the $Z_{\mathrm{m}} / Z_{\text {eu }}$ ratio (of 5 ) giving rise to the critical depth

depth. The critical depth is, of course, not constant, but depending on the time of the year (i.e. on the length of the photoperiod) and on the phytoplankton composition (Tett 1990, Langdon 1993). However, if the critical depth is close to or higher than a $Z_{\mathrm{m}} / Z_{\mathrm{eu}}$ ratio of 5 in Fig. 2, no net photosynthesis is possible in the eastern half of the estuary whereas there will only be a limited net production in the western half of the basin. When it is assumed that the euphotic depth equals the depth to which $0.1 \%$ of the surface light penetrates, net primary production is possible at salinities higher than 15 psu. The question whether a positive carbon balance is a possibility for phytoplankton will be explored later in this paper.

\section{Phytoplankton chlorophyll and gross primary production}

\section{Chlorophyll biomass and daily primary production}

Fig. 3 shows the seasonal changes in phytoplankton biomass, expressed in terms of chl a and gross primary production. Dynamics in phytoplankton biomass and production at Stn 1 showed the pattern normally seen in temperate marine areas. Further up the estuary, the more turbid conditions limited production more to the summer period and the relation between chlorophyll and production became less clear (see also Kromkamp et al, in press).

The average annual chl a concentration was high in the limnic region, where oxygen concentrations were lowest, and decreased sharply to approximately $7 \mathrm{mg}$
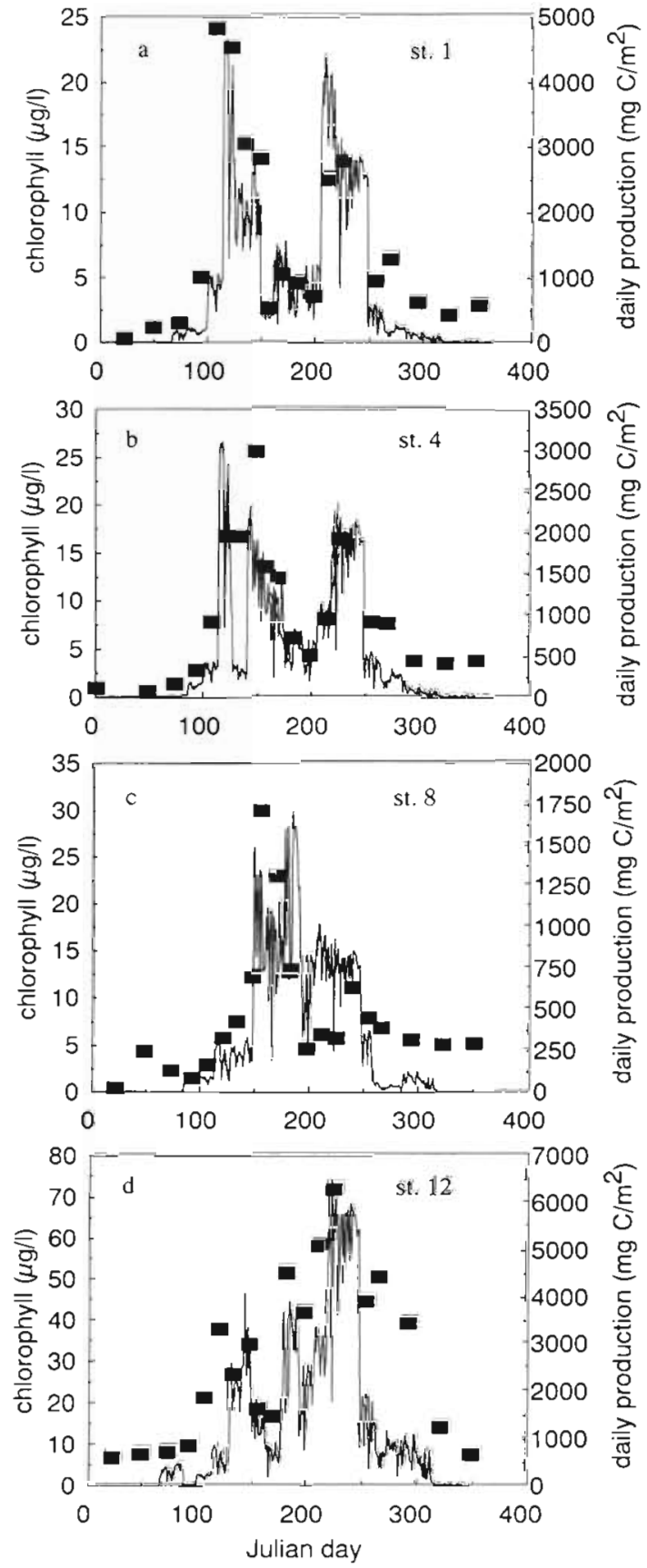

Fig. 3. Change in chlorophyll content ( $\boldsymbol{\square}$ ) and daily production (lines) for 4 representative stations

$\mathrm{m}^{-3}$ and then remained constant at salinities higher than 10 psu (Fig. 4). This sharp decrease cannot be explained by dilution alone. Most likely, phytoplankton coming from the rivers Schelde and Rupel die when they encounter more saline conditions. Also, the main phytoplankton grazers were nearly absent at salinities below 8 psu, decreasing grazing losses in the limnic part (Soetaert et al. 1994, Kromkamp et al. in 


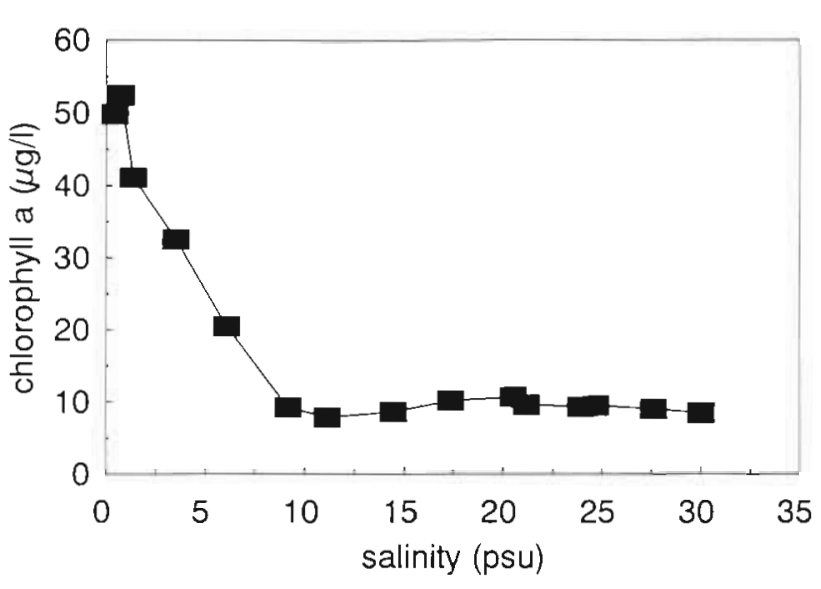

Fig. 4. Change in average chlorophyll concentration (March to December) with salinity

press). A large contribution to the total chl a in these low salinity waters by microphytobenthos and salt marsh plants is unlikely because the area of salt marshes and intertidal flats is small compared to the central and western parts of the basin. The average summer chl a/chl $c$ ratio (Fig. 5) shows a change in the phytoplankton composition at salinities above 10 psu. The chl a-and b-containing green algae which dominated phytoplankton populations in the limnic region (Kromkamp unpubl.) were replaced by a chl a- and ccontaining phytoplankton population dominated by diatoms. Diatoms dominated the phytoplankton in the Dutch part of the Westerschelde (Stns 1 to 9) (Koeman et al. 1992). Interestingly, the replacement of green algae by diatoms seemed to take place after the freshwater phytoplankton had died (i.e. after the strong decrease in biomass).

Annual gross production ranged between 150 and $300 \mathrm{~g} \mathrm{C} \mathrm{m}^{-2}$ in the western part, decreased to less than $100 \mathrm{~g} \mathrm{C} \mathrm{m}^{-2}$ in the eastern part and rose sharply to high values $\left(500 \mathrm{~g} \mathrm{C} \mathrm{m}^{-2}\right)$ in the limnic region of the basin (Antwerpen and upstream, Fig. 6). Values were similar to those observed 2 yr before, with the exception of Stn 12 (Antwerpen), where annual production was twice as high in 1989 (Van Spaendonk et al. 1993). Total production for the Westerschelde was estimated at $55300 \mathrm{t} \mathrm{C} \mathrm{yr}^{-1}$.

Notice that the rise in chl $a$ in the Schelde ( 7 -fold) is much higher than the 2 -fold rise in production in this area compared to the marine part of the estuary. This can be explained by the $P / B$ ratios (carbon turnover rates, Fig. 7), which increase in more saline waters, suggesting higher growth rates in this stretch of the estuary: $P / B$ ratios calculated from gross production rates (i.e. no correction for respiratory losses) were below 0.3 for Stns 12 (Fig. 7a, 2.6 psu) and 8 (Fig. 7b, $14.5 \mathrm{psu}$, with the exception of a period in July, when

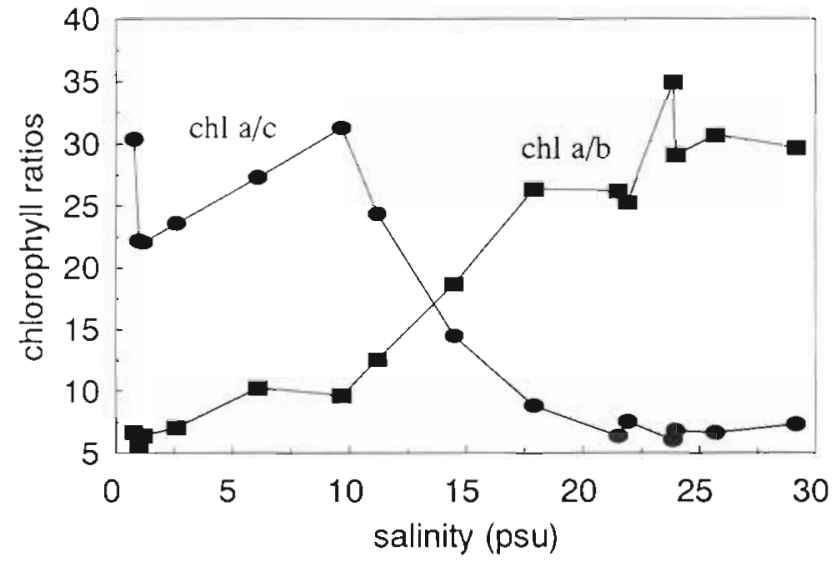

Fig. 5. Change in the ratios of chl $a / c h l b$ and $c h l a / c h l ~ c$ with salinity. Data are the mean values for the summer months (April to September)

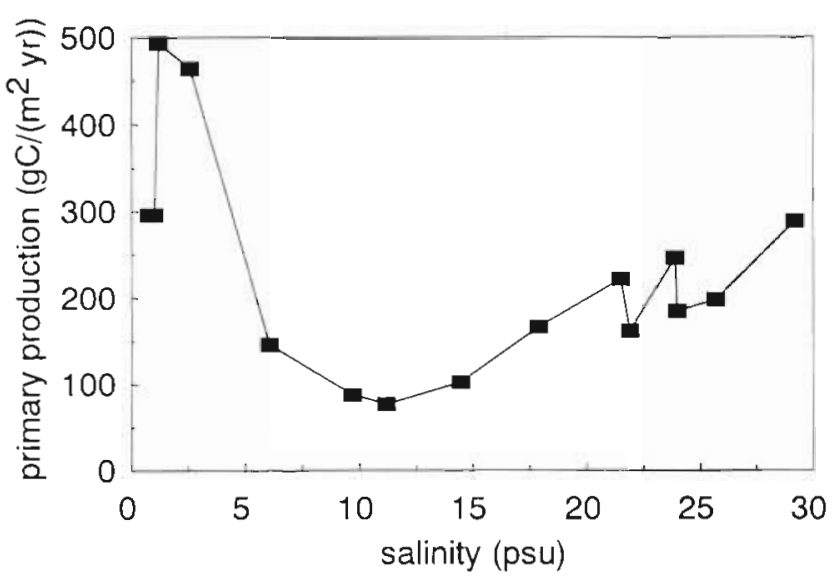

Fig. 6. Annual gross primary production at different salinities

rates above $0.5 \mathrm{~d}^{-1}$ were measured). In summer, turnover rates were above $0.3 \mathrm{~d}^{-1}$ for Stn 4 (Fig. $7 \mathrm{c}$ ) and above $0.4 \mathrm{~d}^{-1}$ for the marine Stn 1 (Fig. $7 \mathrm{~d}$ ). Turbidity is high in the Schelde Estuary, and respiratory losses will be high. It is therefore better to calculate the $P / B$ ratios (which is a measure for the growth rate) from net primary production rates. Net production rates were calculated assuming that respiration rates were $5 \%$ of the assimilation ratio (photosynthetic capacity). Although this is at the low end of the reported range of respiration rates (Langdon 1993 and references therein), we have observed respiration rates like these often in our light-limited continuous cultures of diatoms and green algae. $P / B$ ratios calculated on these net production rates are nearly always negative, indicating that algal growth is not possible and that populations will decline and collapse (Fig. 7). Upon lowering the respiration rate to $2.5 \%$ of $P_{\text {max }}^{B}$, significant positive turnover rates 

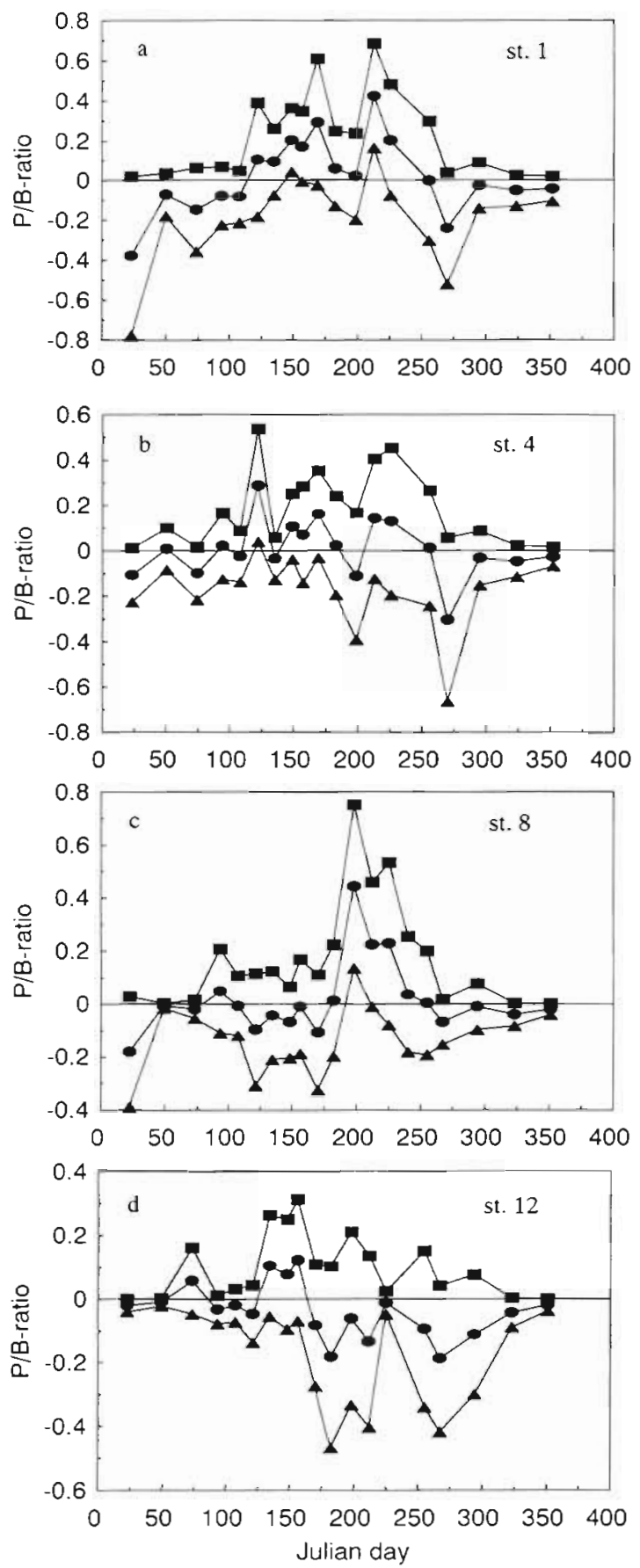

Fig. 7. P/B ratios for 4 representative stations. (a) Respiration, $R=0 \%$ of $P_{\text {maxi }}^{B}\left(-R=2.5 \%\right.$ of $P_{\text {maxi }}^{B}(\Delta) R=5 \%$ of $P_{\max }^{B}$

for prolonged periods during the summer were only observed for stations with a salinity above 20 psu. However, respiration rates below $5 \%$ of the assimilation rate are generally considered not to occur

Freshwater phytoplankton coming down the rivers Schelde and Rupel encounter more saline conditions,
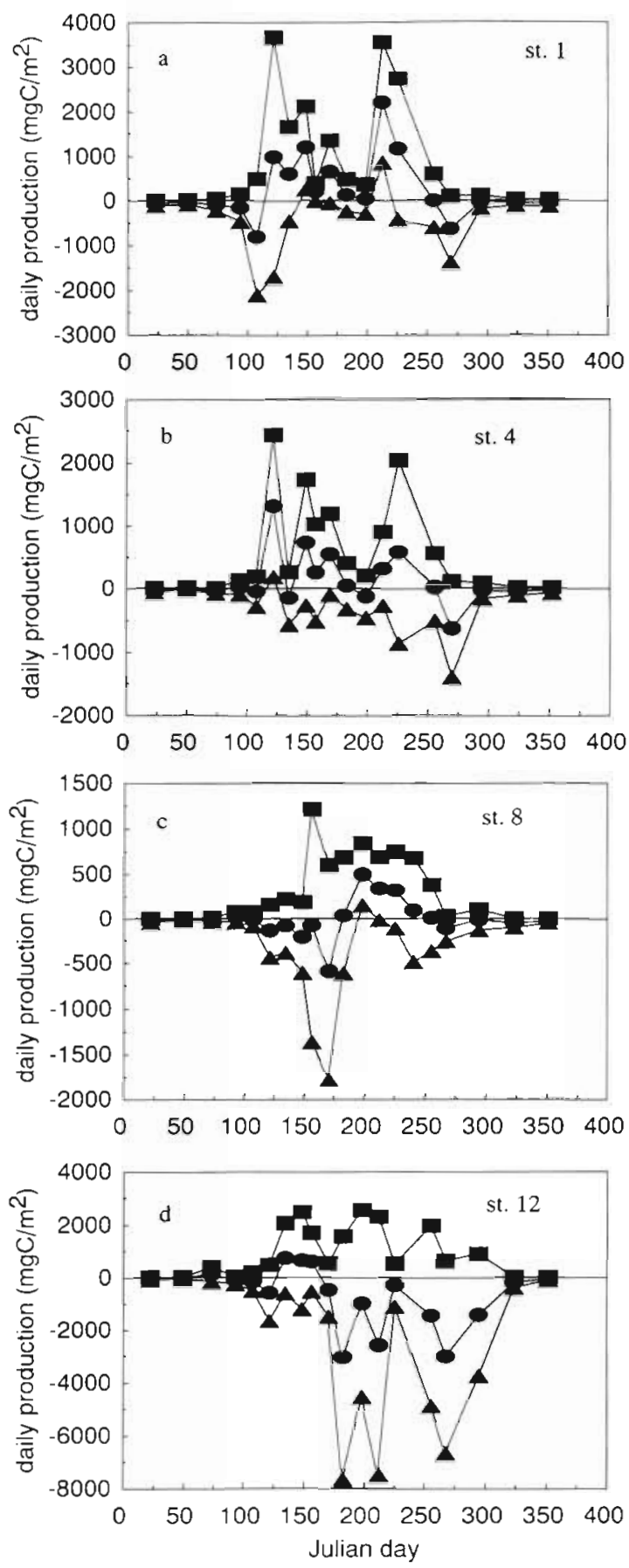

Fig. 8. Daily net production for the 4 selected stations (as in Fig. 7). (a) Gross production (no respiration); (O) $R=2.5 \%$ of $P_{\max }^{B}(\boldsymbol{\Delta}) R=5 \%$ of $P_{\max }^{B}$

which are likely to stimulate their rate of respiration (Flameling \& Kromkamp 1994). Hence, respiration rates are likely to be higher in the limnic part than in the other parts of the estuary, and as a consequence, the calculated net $P / B$ ratios are probably underestimations. 
Photosynthetic parameters

Photosynthetic capacities were low in winter and normally reached their maximum in summer (Table 1). Minimum values were lower in the limnic region than in the marine region (not shown). The average summer values (June to September) increased from $8.1( \pm 2.0)$ in the inner estuary ( 1 to 3 psu) to $10.7( \pm 0.9)$ in the middle estuary ( 3 to $20 \mathrm{psu}$ ) to $12.2\left( \pm 1.0 \mathrm{mg} \mathrm{C} \mathrm{mg}^{-1}\right.$ chl $\mathrm{h}^{-1}$ ) in the outer estuary (20 to $30 \mathrm{psu}$ ). Like the photosynthetic capacity, $\alpha^{B}$ showed a clear seasonal cycle. In contrast to $P_{\max }^{B}$ no spatial differences were observed in the summer values of $\alpha^{B}$. The minimum values, however, were lower in the limnic region (Table 1). In the limnic region the standard deviations of $P_{\text {max }}^{B}$ and $\alpha^{B}$ are high. This was due to some very low values of both parameters, most likely caused by an amount of chl a from 'unhealthy' or dying phytoplankton populations which had difficulties with the increasing salinity upon entering the estuary. Because dark fixation rates were subtracted from the light bottles, the high standard deviations in the photosynthetic parameters $P_{\text {max }}^{B}$ and $\alpha^{B}$ in the low salinity range were not caused by chemosynthetic incorporation of ${ }^{14} \mathrm{CO}_{2}$.

\section{Effect of different estimates of respiration on net primary production}

It is not possible to measure phytoplankton respiration rates $(R)$ with the ${ }^{14} \mathrm{C}$ method. Therefore, we assumed that respiration was a fixed proportion of $P_{\text {max }}^{B}$. We also assumed that the measured rates of primary production were gross rates $\left(P_{\mathrm{G}}\right)$, which seems a fair assumption considering the short incubation times used (Williams, 1993). Hence, net production $\left(P_{\mathrm{N}}\right)$ is calculated as $P_{\mathrm{N}}=P_{\mathrm{G}}-R$.

Fig. 8 a to $d$ shows the net daily rates of production calculated for 4 selected stations. At Stn 12 (Fig. 8d), no net areal production could be calculated when $R$ was taken as $5 \%$ of $P_{\text {max }}^{B}$. The same was true for the other stations, with the exception of 2 sampling days at the marine Stn 1 (Fig. 8a). When the respiration rate was taken as $2.5 \%$ of $P_{\max }^{B}$, i.e. only during the spring bloom period, net primary production was calculated at Stn 12, during the rest of the year $R$ was $>P_{6}$. The period and the magnitude of the positive net production with this assumed respiration rate increased towards the sea, reflecting the improved light conditions (Fig. 9). Annual production was never positive when $R$

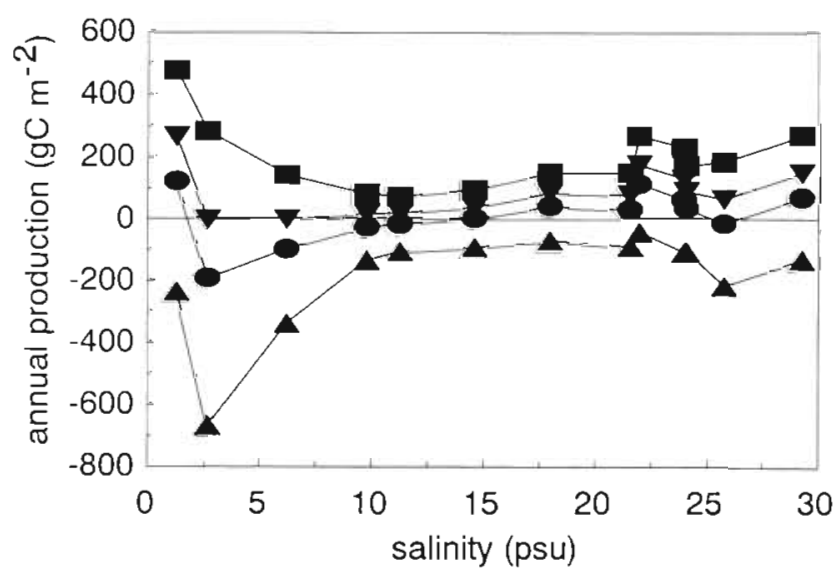

Fig. 9. Net annual production at the different stations. Gross production; ( $\nabla)$ net production when $R=1.5 \%$ of $P_{\text {muxi }}^{B}$; (O) net production when $R=2.5 \%$ of $P_{\text {max; }}^{B}$ ( $\Delta$ ) net production when $R=5 \%$ of $P_{\max }^{B}$. In calculating annual production we interpolated linearly between sampling points. This gave small differences for the gross production $(R=0)$ when compared to the data presented in Fig. 6

was taken as $5 \%$ of $P^{B}{ }_{\max }$. Also, when $R$ was taken as $2.5 \%$ of the photosynthetic capacity, net annual production for the inner estuary was only observed in the freshwater Stn 13, just upstream of Antwerpen. In the salinity range of 2 to $15 \mathrm{psu}$, no phytoplankton growth was possible. At more saline conditions, gross production was slightly higher than calculated respiration. Even when $R$ is $1.5 \%$ of $P_{\text {max }}^{B}$, no net production takes place in the inner Westerschelde. One might doubt though that respiration rates below $5 \%$ of the photosynthetic capacity are physiologically feasible (see Langdon 1993 for a recent review on respiration rates).

Table 1. Minimum and maximum photosynthetic capacities as well as the average (Avg) and standard deviation in $P_{\max }^{P}$ and $\alpha^{B}$ for Days 150 to 257 ( $\mathrm{n}=7$ or 8 ) at several stations. Average salinity at each station is given

\begin{tabular}{|cccccc|}
\hline $\begin{array}{c}\text { Salinity } \\
\text { (psu) }\end{array}$ & Stn & $\begin{array}{c}p^{B}{ }_{\max } \\
\text { Min-max }\end{array}$ & $\begin{array}{c}p^{B} \text { max } \\
\text { Avg (SD) }\end{array}$ & $\begin{array}{c}\alpha^{B} \\
\text { Min-max }\end{array}$ & $\begin{array}{c}\alpha^{B} \\
\text { Avg (SD) }\end{array}$ \\
\hline 0.8 & 15 & $0.7-18.8$ & $8.0(6.2)$ & $0.005-0.080$ & $0.032(0.026)$ \\
1.0 & 14 & $0.9-15.0$ & $8.1(5.1)$ & $0.006-0.070$ & $0.033(0.023)$ \\
1.2 & 13 & $0.7-13.0$ & $5.8(5.2)$ & $0.006-0.059$ & $0.024(0.022)$ \\
2.6 & 12 & $0.6-14.3$ & $10.6(4.3)$ & $0.005-0.055$ & $0.042(0.017)$ \\
6.1 & 11 & $0.9-9.7$ & $9.7(2.0)$ & $0.005-0.054$ & $0.036(0.010)$ \\
9.7 & 10 & $0.9-16.2$ & $10.3(2.7)$ & $0.007-0.051$ & $0.037(0.008)$ \\
11.2 & 9 & $0.6-15.7$ & $11.2(2.1)$ & $0.006-0.055$ & $0.037(0.009)$ \\
14.5 & 8 & $0.5-15.4$ & $11.7(2.4)$ & $0.002-0.055$ & $0.038(0.011)$ \\
17.9 & 7 & $1.4-16.4$ & $12.5(2.5)$ & $0.008-0.052$ & $0.041(0.009)$ \\
21.5 & 6 & $1.5-18.1$ & $12.9(4.0)$ & $0.009-0.060$ & $0.042(0.011)$ \\
21.9 & 5 & $1.7-12.8$ & $10.3(1.9)$ & $0.012-0.048$ & $0.034(0.005)$ \\
23.9 & 4 & $2.3-17.9$ & $12.5(3.1)$ & $0.012-0.064$ & $0.039(0.002)$ \\
24.0 & 3 & $2.1-16.2$ & $12.4(2.3)$ & $0.014-0.053$ & $0.038(0.004)$ \\
25.7 & 2 & $1.9-16.2$ & $12.7(2.8)$ & $0.012-0.053$ & $0.042(0.008)$ \\
29.2 & 1 & $3.1-15.9$ & $12.6(2.6)$ & $0.021-0.066$ & $0.043(0.010)$ \\
\hline
\end{tabular}


Thus, from the calculations shown so far it appears that the algae respire more carbon than they produce by means of photosynthesis. Alternative views will, however, be discussed below.

\section{DISCUSSION}

The initiation of the spring bloom in aquatic environments is generally explained by the critical depths hypothesis (Sverdrup 1953 in Smetacek \& Passow 1990, Tett 1990). In most estuaries, the seston content is high which causes poor light conditions. In an analysis of phytoplankton primary production in San Francisco Bay (California, USA), it was concluded that when the ratio of the mixing depth to the euphotic depth $\left(Z_{\mathrm{m}} / Z_{\text {eu }}\right)$ is smaller than 6 , net primary production is possible and a bloom can be initiated (Cole \& Cloern 1984, Alpine \& Cloern 1988). Other authors obtained the same ratio (Grobbelaar 1985, Tett 1990), although Grobbelaar argued that the ratio can be much higher (Grobbelaar 1990). In the present study, the mixing depth is taken as the average water depth of each compartment. It is clear from Fig. 2 that when a $Z_{\mathrm{m}} / Z_{\text {eu }}$ ratio of 5 to 6 is used, hardly any phytoplankton growth would be possible in the Westerschelde. Our estimates of net primary production also seem to indicate that net phytoplankton growth is not possible: $P / B$ ratios based on net primary production estimates with a low respiration rate $\left(R=5 \%\right.$ of $\left.P_{\text {max }}^{B}\right)$ were generally negative, and net annual production rates were also negative. The $\mathrm{C} / \mathrm{ch}$ l a ratio is known to be dependent on environmental conditions (Geider et al. 1986). However, changing the $\mathrm{C} / \mathrm{chl}$ a ratio to 20 to $50 \mathrm{did}$ not lead to a different conclusion for calculations of net primary production based on the assumption that $R=5 \%$ of $P_{\text {max }}^{B}$ as the $\mathrm{C} / \mathrm{Chl}$ a ratio does not enter the calculations on net production. A different $\mathrm{C} / \mathrm{chl}$ a ratio only changed the dynamics in the $P / B$ ratios: i.e. a negative net $P / B$ ratio became more negative, whereas a positive $P / B$ ratio increased more upon lowering the $\mathrm{C} / \mathrm{chl}$ a ratio; a higher $\mathrm{C} / \mathrm{chl}$ a ratio seems to dampen out the seasonal changes (not shown). Unrealistically low respiration rates were necessary for net primary production to be calculated. Still it is hard to believe that no phytoplankton growth occurred, since the chlorophyll dynamics strongly suggest that phytoplankton growth did happen. Indeed, in a general ecosystem model for the Westerschelde we found that import of algae across the freshwater and marine end members could not explain the observed dynamics in phytoplankton biomass, although it did show that import processes were important (Soetaert et al. 1994). From this we must conclude that the critical $Z_{\mathrm{m}} / Z_{\text {eu }}$ ratio in the Westerschelde must be larger than 5 and that consequently net primary production did occur. Generally, the water layer up to the $1 \%$ light level is taken as the euphotic depth (during the photoperiod). This is probably not correct. We have measured net photosynthetic oxygen evolution frequently below this light level in cultures (not shown), and the compensation light level is therefore often smaller than $1 \%$ of the surface irradiance. If we take the $0.1 \%$ depth as the compensation depth and recalculate the mean $Z_{\mathrm{m}} / Z_{\mathrm{eu}}$ ratios (and assume that this gives a better indication of the critical depth), we see that net production is possible downstream from Str 9 (salinity of $>11$ psu). The same conclusion can be drawn when the net annual primary production is calculated assuming respiration to be $1.5 \%$ of $P_{\text {max }}^{B}$. This hypothesis is corroborated by the results of the Westerschelde ecosystem model (Soetaert et al. 1994), which also suggest that net phytoplankton primary production occurred downstream from Stn 9.

Cole et al. (1992) concluded that phytoplankton net primary production was not possible in the turbid freshwater Rhode River Estuary and that phytoplankton biomass was 'imported' by advection from shallow areas in the estuary. In the Westerschelde resuspension of benthic algae from the intertidal mudflats might be responsible for part of the observed biomass, but the maximal surface area of the intertidal flats is approximately $25 \%$ of the total surface area in the Westerschelde (De Jong \& de Jonge in press). Benthic microalgal primary production can be an important part of total algal primary production in estuaries. Sullivan \& Moncreiff (1988) estimated benthic microalgal primary production to be $30 \%$ of total primary production in a Mississippi (USA) salt marsh. Colijn (1983) found that primary production by microphytobenthos was $20 \%$ of total production in the Ems-Dollard Estuary. Kromkamp et al. (in press) and De Jong \& de Jonge (in press) argue that microphytobenthos production in the Westerschelde is less than $15 \%$ of phytoplankton production, and it is therefore unlikely that microphytobenthos resuspension alone can explain the observed chlorophyll dynamics.

Our model to calculate net production is very much dependent upon the respiration rate and the specific photosynthetic parameters. All of our photosynthesis light data were fitted with the iterative method of Eilers \& Peeters (1988) because they gave the best fit. We, however, also used the fit methods of Platt \& Jassby (1976) and Platt \& Gallegos (1980). Using the 3 fits, the gross primary production was calculated taking the basin morphology into consideration. Differences in calculated areal production with the different fit methods were not significantly different. In general, the Eilers \& Peeters method gave slightly higher $P^{B}{ }_{\text {max }}$-values, but the differences were small and not significant (Table 2). The Platt \& Gallegos fit gave the highest $\alpha^{B}$. 
Table 2. Annual average rates of $P_{\max }^{B}$ and comparisons between $P_{\max }^{B}$ and $\alpha^{B}$ between the fit-methods (in \%) of Eilers \& Peeters (EP, 1988), Platt \& Jassby (PJ, 1976) and Platt \& Gallegos (PG, 1980) for 4 selected stations

\begin{tabular}{rrrrrr|}
\hline \multirow{2}{*}{ Stn } & & $P_{\text {max }}^{B}$ & & \multicolumn{2}{c|}{$\alpha^{B}$} \\
& EP & PJ/EP & PG/EP & PJ/EP & PG/EP \\
\hline 12 & 6.91 & 100.0 & 96.8 & 104.4 & 118.2 \\
8 & 7.73 & 93.7 & 90.7 & 103.8 & 118.5 \\
4 & 8.95 & 97.6 & 95.6 & 104.1 & 116.8 \\
1 & 9.70 & 99.0 & 98.1 & 104.9 & 116.2 \\
\hline
\end{tabular}

values: they were on average $17 \%$ higher than when calculated using the Eilers \& Peeters method. The higher photosynthetic efficiencies calculated with the Platt \& Gallegos method, however, did not lead to higher areal production values. Apparently, the gain in carbon fixation at low light intensities is lost at higher irradiances because this fit method gave rise to high rates of photoinhibition. The photosynthetic efficiencies we report are at the high end of the range as reported for selected coastal areas and estuaries in North America (Keller 1988). If we take $50 \%$ of our mean $\alpha^{B}$-values [i.e. from ca 0.034 to $0.017 \mathrm{mg} \mathrm{C}$ $\mathrm{mg}^{-1} \mathrm{chl} \mathrm{h}^{-1}\left(\mu \mathrm{mol} \mathrm{m} \mathrm{m}^{-2} \mathrm{~s}^{-1}\right)^{-1}$ ), the areal production decreases by $40 \%$. Hence, the net primary production will be very much dependent on large changes in the photosynthetic efficiency. This is contrary to results found for the turbid Hudson River Estuary by Cole et al. (1992): they argued that in shallow waters (or in rather transparent waters) higher values of $\alpha^{B}$ would lead to higher net production rates, but that in deeper waters the net areal production is not very sensitive to the value of $\alpha^{B}$. If changes in $\alpha^{B}$ can have such large effects, then spectral changes with depth might be important. In the Schelde Estuary (Kromkamp unpubl. results), blue light is rapidly absorbed and the photosynthetically usable radiation might decrease by as much as $40 \%$ in the first meter. This means that the photosynthetic efficiency will decrease $\left(\alpha^{B}=a^{*}{ }_{p h} \Phi\right.$, where $a^{*}$ ph is the algal absorption per mg chlorophyll and $\Phi$ the quantum efficiency of photosynthesis) because the absorption of light by phytoplankton will decrease. Thus, according to this reasoning, our calculated net production rates are possibly too high. When we compared our $P_{\text {max }}^{B}$-values with those reported in the literature, no indications of methodological errors were observed: our mean and maximum values correspond very close to mean values found for coastal and estuarine systems in North America (Keller 1988) and Europe (Colijn 1983, Wetsteyn \& Kromkamp 1994).

It is probably better to divide respiration into a constant maintenance respiration (needed for cell integrity, osmotic balance, etc.) and a variable respira- tion dependent on the growth rate (Laws \& Bannister 1980, Falkowski et al. 1985, Geider \& Osborne 1986). Using this information, Langdon (1993) developed a 2component model of algal respiration, which also allowed respiration in the light to be different from respiration in the dark, as was shown to be the case for several algae by Grande et al. (1989) and Weger et al. (1989). The respiration over the entire water column $\left(R_{\mathrm{z} 1}\right)$ can be modelled as:

$$
R_{z t}=B Z\left[24 D R_{0}+(24-D) R_{\mathrm{D}} P_{z t}^{B}+D R_{\mathrm{D}} R_{\mathrm{L}} P_{z t}^{B}\right]
$$

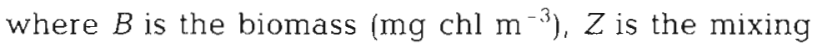
depth, $D R_{0}$ is the biomass-specific maintenance respiration ( $\left.\mathrm{mg} \mathrm{O}_{2} \mathrm{mg}^{-1} \mathrm{ch} \mathrm{h}^{-1}\right), D$ the daylength, $R_{\mathrm{D}}$ is the growth rate (or better: photosynthesis) dependent linear coefficient of dark respiration $\left(\mathrm{mg} \mathrm{O}_{2} \mathrm{mg}^{-1} \mathrm{Chl} \mathrm{h}^{-1}\right)$, $P^{B}{ }_{z t}$ is $P_{z t} /(D B Z), P_{z l}$ is the primary production in the water column ( $\mathrm{mg} \mathrm{C} \mathrm{m} \mathrm{m}^{-2} \mathrm{~d}^{-1}$ ), and $R_{\mathrm{L}}$ the ratio of light to dark respiration (Langdon 1993). Using this model and values of the coefficients as suggested by Langdon (see legend Fig. 10), we calculated which proportion of the gross photosynthesis was respired at the marine Stn 1 . The maintenance respiration $\left(D R_{0}\right)$ was taken as $0.048 \mathrm{mg} \mathrm{O}_{2} \mathrm{mg}^{-1} \mathrm{chl} \mathrm{h}^{-1}$, a value typical for diatoms (Langdon 1993). When the respiration coefficient related to growth $\left(R_{\mathrm{D}}\right)$ was taken as that suggested to be representative for diatoms $\left(1.024 \mathrm{mg} \mathrm{O}_{2} \mathrm{mg}^{-1} \mathrm{chl}\right.$ $\mathrm{h}^{-1}$; Langdon, 1993), the ratio $R_{z t} / P_{z t}$ was smaller than when it was assumed that $R$ was $1.5 \%$ of $P_{\max }^{B}$. However when $R_{D}$ was doubled to $2.048 \mathrm{mg} \mathrm{O}_{2} \mathrm{mg}^{-1} \mathrm{chl}$ $h^{-1}$, the amount respired sometimes matched the amount calculated with the assumption that $R$ was $1.5 \%$ of $P_{\max }^{B}$ (Fig, 10), although in most cases, it remained lower. When values were chosen that were representative of Prymnesiophytes, the $R_{z t} / P_{z t}$ ratio behaved more or less the same as when $R$ was taken as $1.5 \%$ of $P_{\text {max }}^{B}$. The fact that model values taken as representative for Prymnesiophytes gave the best results corresponds to the fact that a large part of the spring and late summer bloom at Stn 1 was caused by the Prymnesiophyte Phaeocystis pouchetii.

We tried to estimate respiratory losses in 2 ways in order to calculate net primary production. Our results show that the approach to calculate net production from gross production by assuming that the respiration is a fixed percentage of the photosynthetic capacity did lead to higher values (overestimates) of respiratory losses (when normally assumed values for the respiration are used, i.e. between 5 and $20 \%$ of $P_{\max }^{B}$ ) than when using Langdon's (1993) 2-compartment model (which also uses published data from culture studies). Respiration rates below $5 \%$ of the photosynthetic capacity are considered very low and it is doubtful whether they are physiologically meaningful. One might argue, however, that algae in turbid estuaries 


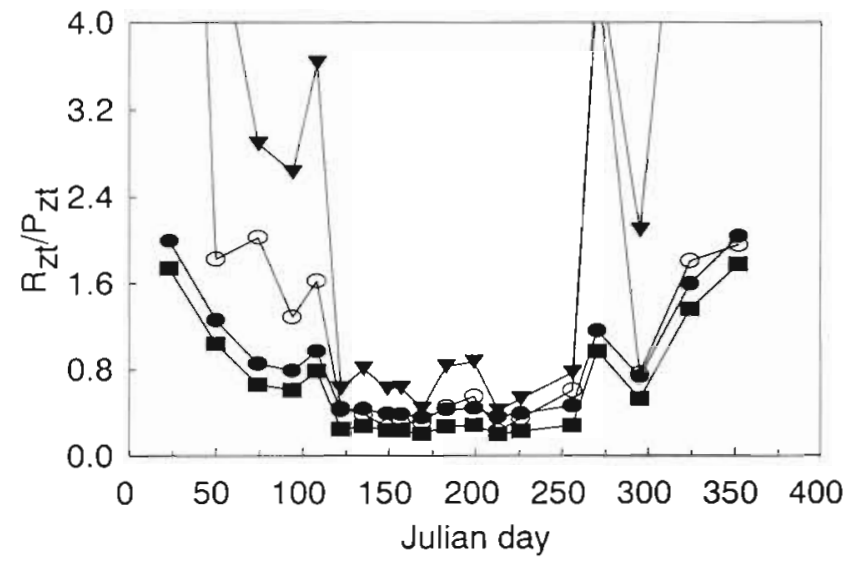

Fig. 10. Comparison of respiration $\left(R_{z l}\right)$ to gross production $\left(P_{z l}\right)$ for the whole water column at Stn 1 using 2 different models to calculate respiration. For the first model, Eq. (2) (in text) is used: ( $\square$ ) biomass-specific maintenance respiration $\left(D R_{0}\right)=0.048 \mathrm{mg} \mathrm{O}_{2} \mathrm{mg}^{-1} \mathrm{chl} \mathrm{h}^{-1}$, the photosynthesis-dependent lineral coefficient of dark respiration $\left(R_{\mathrm{D}}\right)=1.024 \mathrm{mg} \mathrm{O}$ $\mathrm{mg}^{-1} \mathrm{chl} \mathrm{h} \mathrm{h}^{-1}$ and the ratio of light to dark respiration $\left(R_{\mathrm{L}}\right)=2$, values typical for diatoms; (O) same values except that $R_{\mathrm{D}}$ is doubled to 2.048 ; (O) $D R_{0}=0.272, R_{\mathrm{D}}=1.872$ and $R_{\mathrm{L}}=1$, values typical for Prymnesiophytes. For the second model ( $\nabla$ ) we assumed that $R=1.5 \%$ of $P_{\text {max }}^{E}$

hardly ever photosynthesize at their maximum rate for a period longer than a few minutes. However, unpublished $P / I$ curves made from samples of cultures of light-limited algae nearly always show that respiration rates are more than 4 to $5 \%$ of the photosynthetic capacity, even when the $P / I$ curve is made at the end of the dark period. Hence, the results from culture studies contradict the results discussed in this paper. One reason for this might be that cultures are seldom axenic and that bacteria contribute to the dark respiration. Bacterial biomass in algal cultures is normally insignificant in comparison to algal biomass and consequently, bacterial respiration will only be a small proportion of the total dark respiration. A more likely explanation might be that algal cultures are adapted to the constant conditions under which they are grown. It was shown by Loogman (1982) and Post et al. (1986) that continuous cultures of the cyanobacterium Oscillatoria agardhii and the green alga Scenedesmus protuberans grown with different light/dark cycles adapted the rates at which they increased their carbohydrate content during the day and respired it during the following dark period according to the length of the light period. Hence, these algae were 'trained' to their environmental conditions and the respiration rates were a reflection of these conditions. Algae in the natural environment, especially in turbid, well-mixed temperate estuaries, will seldom experience constant conditions. Hence, they are in a condition of unbalanced growth, in contrast to most algae in cultures, especially continuous cultures, where algae are in a condition of balanced growth. It might be that under conditions of unbalanced growth, respiration will decrease as soon as the algae enter darkness. Also, phytoplankton cultures exposed to a fluctuating light climate might increase their $P_{\text {max }}^{B}$ as shown for the marine diatom Skeletonema costatum (Kromkamp \& Limbeek 1993), in contrast to cultures grown with a simple light/dark cycle or with continuous light. Because natural phytoplankton experience fluctuating light as they circulate through the light gradient, this might be another reason for the fact that when respiration is estimated by assuming it is equal to $5 \%$ of $P_{\text {max }}^{B}$, respiratory losses might be overestimated.

Research is needed on the regulation of respiration and the growth kinetics of algae under conditions of unbalanced growth. The data gathered by Langdon (1993) in his review come from algal cultures and are partly based on mass balances. Use of the data presented by Langdon in combination with gross primary production rates determined by us makes it more likely that respiration rates below $5 \%$ of $P_{\max }^{B}$ do indeed occur.

Acknowledgements. We like to thank the crew of the RV 'Luctor' for assistance in the field, Jan Sinke for the determinations of the pigments the staff of the 'bodemlab' for seston analyses and the referees for their useful comments, which helped to improve the manuscript. This is communication 753 of the NIOO-CEMO.

\section{LITERATURE CITED}

Alpine AE, Cloern JE (1988) Phytoplankton growth rates in a light-limited environment. San Francisco Bay. Mar Ecol Prog Ser 44:167-173

Billen G, Lancelot C, De Becker E, Servais P (1988) Modelling microbial processes (phyto- and bacterioplankton) in the Schelde Estuary. Hydrobiol Bull 22:43-55

Cadee G (1993) Persisting high levels of primary production at declining phosphate concentrations in the Dutch coastal area (Marsdiep). Neth J Sea Res 31:147-152

Cloern JE (1987) Turbidity as a control on phytoplankton biomass and productivity in estuaries. Cont Shelf Res 7 $1367-1381$

Cole BE, Cloern JE (1984) Significance of biomass and light availability to phytoplankton productivity in San Fransisco Bay. Mar Ecol Prog Ser 17:15-24

Cole JJ, Caraco NF, Peierls BJ (1992) Can phytoplankton maintain a positive carbon balance in a turbid, freshwater, tidal estuary? Limnol Oceanogr 37:1608-1617

Colijn F (1983) Primary production in the Ems-Dollard estuary. PhD thesis, University of Groningen

De Jong $D J$, de Jonge VN (in press) Dynamics of microphytobenthic chlorophyll-a in the Scheldt estuary (SW Netherlands). Hydrobiologia

Eilers P, Peeters JCH (1988) A model for the relationship between light intensity and the rate of photosynthesis in phytoplankton. Ecol Model 42: 199-215 
Falkowski PG, Dubinsky Z, Wyman K (1985) Growth-irradiance relationships in phytoplankton. Limnol Oceanogr 30: 311-321

Fichez R, Jickells TD, Edmunds HM (1992). Algal blooms in high turbidity, a result of the confilicting consequences of turbulence on nutrienc cycling in a shallow water estuary. Estuar coast Shelf Sci 35:577-592

Flameling l, Kromkamp J (1994) Responses of respiration and photosynthesis of Scenedesmus protuberans Fritsch to gradual and steep salinity increases. J Plankton Res 16: $1781-1791$

Geider RJ, Osborne BA (1986) Light absorption, photosynthesis and growth of Nannochloris atomus in nutrient-saturated cultures. Mar Biol 93:351-360

Geider RJ, Platt T, Raven JA (1986) Size dependence of growth and photosynthesis in diatoms: a synthesis. Mar Ecol Prog Ser 30:93-104

Gieskes WWC, Kraay GW, Nontji A, Setiapermana D, Sutomo (1988) Monsoonal alternation of a mixed and layered structure in the phytoplankton of the euphotic zone of the Banda Sea (Indonesia), a mathematical analysis of algal pigment fingerprints. Neth J Sea Res 22:123-137

Goosen NK, Van Rijswijk P, Peene J, Kromkamp J (1992). Annual patterns of bacterial production in the Scheldt estuary (SW-Netherlands). In: Herman PMJ (ed) JEEP 92: major biological processes in European tidal estuaries. NIOO-CEMO (MAST)-report of Faro Workshop, Plymouth 1992. Netherlands Institute of Ecology, Centre for Estuarine and Coastal Ecology, Yerseke, p 109-113

Grande KD, Marra J, Langdon C, Heinemann KR, Bender ML (1989) Rates of respiration in the light measured in marine phytoplankton using an ${ }^{18} \mathrm{O}$ isotope labelling technique. J exp mar Biol Ecol 129:95-120

Grobbelaar JU (1985) Phytoplankton productivity in turbid waters. J Plankton Res 7:653-663

Grobbelaar JU (1990) Modelling phytoplankton productivity in turbid waters with small euphotic to mixing depth ratios. J Plankton Res 12:923-931

Heip C (1989) The ecology of the estuaries of Rhine, Meuse and Scheldt in the Netherlands. In: Ros JD (ed) Topics in marine biology. Scientia mar 53:457-463

Joint IR, Pomroy AJ (1981) Primary production in a turbid estuary. Estuar coast Shelf Sci 13:303-316

Keller AA (1988) An empirical model of primary productivity $\left({ }^{14} \mathrm{C}\right)$ using mesocosm data along a nutrient gradient. J Plankton Res 10:813-834

Klepper O (1989) A model of carbon flows in relation to macrobenthic food supply in the Oosterschelde estuary (SW Netherlands). PhD thesis, University of Wageningen

Koeman R, Rademaker M, Buma A (1992) Biomonitoring van phytoplankton in de Nederlandse zoute en brakke wateren 1991. Report Tripos/National Institute for Coastal and Marine Management (RIKZ), Rijswijh (The Netherlands), p 1-123

Kromkamp J, Limbeek M (1993) Effect of short-term variation in irradiance on light harvesting and photosynthesis of the marine diatom Skeletonema costatum: a laboratory study simulating vertical mixing. J gen Microbiol 139: $2277-2284$

Kromkamp J, Peene J, Van Rijswijk P, Sandee A, Goosen N (in press) Nutrients, light and primary production by

This article was submitted to the editor phytoplankton and microphytobenthos in the eutropic, turbid Westerschelde Estuary (The Netherlands). Hydrobiologia

Langdon C (1993) The sigficance of respiration production measurements based on both carbon and oxygen. In: $\mathrm{Li}$ WKW, Maestrini SX (eds) Measurement of primary production from the molecular to the global scale, Vol 197 ICESS MSS, International Council for the Exploration of the Sea, Copenhagen, p 69-78

Laws EA, Bannister TT (1980) Nutrient- and light-limited growth of Thalassiosira fluviatilis in continuous culture, with implications for phytoplankton growth in the ocean Limnol Oceanogr 25:457-473

Loogman JG (1982) Influence of photoperiodicity on algal growth kinetics. PhD thesis, University of Amsterdam

Platt T, Gallegos GL (1980) Modelling primary production. In Falkowski PG (ed) Primary production in the sea. Plenum Press, New York, p 339-351

Platt T, Jassby AD (1976) The relationship between photosynthesis and light for natural assemblages coastal marine phytoplankton. J Phycol 12:421-430

Post AF, Loogman JG, Mur LR (1986) Photosynthesis, carbon flows and growth of Oscillatoria agardhiu Gomont in environments with a periodic supply of light. $J$ gen Microbiol 132:2129-2136

Smetacek V, Passow U (1990) Spring bloom initiation and Sverdrups critical-depth model. Limnol Oceanogr 35 $228-234$

Soetaert K, Herman PMJ, Kromkamp J (1994) Living in the twilight: estimating net phytoplankton growth in the Westerschelde estuary (the Netherlands) by means of a global ecosystem model (MOSES). J Plankton Res 16: $1277-1302$

Sullivan M, Moncreiff C (1988) Primary production of edaphic algal communities in a Mississippi salt marsh. J Phycol 24 $49-58$

Tett P (1990) The photic zone. In: Herring PJ, Campbell AK, Whitfield M, Maddock L (eds) Light and life in the sea Cambridge University Press, Cambridge, p 1-357

Van Spaendonk JCM, Kromkamp JC, de Visscher PRM (1993) Primary production of phytoplankton in a turbid coastal plain estuary (The Netherlands). Neth J Sea Res 31: $267-279$

Vegter F, de Visscher PRM (1894) Phytoplankton primary production in brackish lake Grevelingen (SW Netherlands) during 1976-1981. Neth J Sea Res 18:246-259

Weger HG, Herzig R, Falkowski PG, Turpin DH (1989) Respiratory losses in the light in a marine diatom: measurements by short-term mass-spectrometry. Limnol Oceanogr 34:1153-1161

Wetsteyn LMPJ, Kromkamp JC (1994) Turbidity, nutrients and phytoplankton primary production in the Oosterschelde (The Netherlands) before, during and after a large-scale coastal engineering project (1980-1990). Hydrobiologia 282/283:61-78

Williams PJ LeB (1993) Chemical and tracer methods of measuring plankton production. In: Li WKW, Maestrini SY (eds) Measurement of primary production from the molecular to the global scale, Vol 197. ICESS MSS, International Council for the Exploration of the Sea, Copenhagen, $\mathrm{p}$ 20-36

Manuscript first received: February 10, 1994

Revised version accepted: January 21, 1995 